\title{
Functional Recovery after Spinal Cord Injury May Be Achieved by Chondroitinase ABC Treatment
}

\author{
コンドロイチナーゼ ABC による処理は春髄損傷後の機能的回復に有効かもしれない
}

Key Words : chondroitinase ABC, chondroitin sulfate, spinal cord injury, functional recovery

The peoples of ancient Egypt were already aware of paralysis and disfunction of limb and leg that occurred after injury of the spinal cord. Human has suffered from traumatic injury of the spinal cord for a long time, and recovery from the tragic disfunction has been a matter of great concern. Regeneration of the spinal cord primarily requires elongation of axon of neural cells, but glial scars formed after severe injury disturb the elongation. Neurite outgrowth inhibitors such as Nogo, CSPGs and MAG (see notes below) are thought to be responsible for the repression of the axon elongation. CSPGs that are released from the activated astroglia after neural cell damage cause the formation of glial scars. Extracellular matrix contained richly in glial scars seems to prevent the neural fiber from passing through the scar. Continuous administration of chondroitinase $A B C$ (ChABC) into the injury site at the central nervous system immediately after damage of the spinal cord was reported to induce axonal elongation, suggesting that chondroitin sulfate (CS) chains may inhibit the elongation of axon (Moon, L.D., et al., (2001) Nature Neurosci. 4, 465-466). In the paper introduced here (Bradbury, J, E. et al., (2002) Nature, 416, 636-640), the authors showed that continuous delivery of ChABC to the lesioned dorsal columns of adult rats promoted functional recovery of locomotive activity. The methods described in this paper may be applicable to treatment of human spinal injuries.

A cervical (C4) dorsal column crush lesion was performed in adult Wister rats. Concurrently, a silastic tube was inserted intrathecally to the lesion site. Immediately after the lesion, $6 \mu \mathrm{l}$ $\mathrm{ChABC}(10 \mathrm{U} / \mathrm{ml})$ was injected. A further group received the spinal cord lesion with saline treatment. ChABC or control solution was delivered on alternate days for 10 days after lesion. Control animals received sham surgery. Rats were perfused at two weeks after lesion and degradation of CS at the injury site was assessed with the antibody $2 \mathrm{~B} 6$, which recognizes unsaturated 4-sulfated disaccharide stab attached to the core protein. Degradation of CS was observed in the lesioned rats treated with $\mathrm{ChABC}$ around the lesion site and in white matter tracts extending at least $4 \mathrm{~mm}$. Expression of growth-associated protein 43 that is associated with a regenerative state of neuron was upregulated in dorsal root ganglion neurons near the lesioned sites treated by ChABC. Cholera toxin B-subunit that binds GM1 expressed in functional axons stained thick fiber bundles approaching the lesion sites in lesioned animals that received $\mathrm{ChABC}$ infusion. Growth-cone-like endings were apparent on
春髄に損傷を受けると四肢麻痺や機能不全が起こるという 記載は、紀元前の古代エジプトにまで遡ることができるという。 人類にとって外傷的脊髄損傷は不可避的に起こりつづけており、 その悲劇的機能障害の回復は古くから関心が寄せられていた。 脊髄再生の第一歩は神経細胞の伸長であるが、ひどい損傷ほど グリア瘕痕が形成されて神経細胞は伸長しない。神経細胞の伸 長を抑制しているのは神経伸展阻害物質である Nogo、CSPGs、 MAG(脚注参照)などであるが、中でも CSPGsは神経損傷後の活 性型アストログリアから放出され、グリア㓔痕を形成する。グ リア瘕痕は豊富な細胞外基質から構成されていて、その表面で 神経線維を通過させない原因となっているという。また脊髄損 傷のような中枢神経系の損傷部位へ、損傷後すぐにChABCを持 続的に投与すると、軸索伸長が見られるようになるという報告 もある(Moon, L.D., et al., (2001) Nature Neurosci. 4, 465-466)。こ れはコンドロイチン硫酸(CS)鎖が軸索伸展の障害となっている ことを示唆するものである。今回紹介する論文 (Bradbury, J, E. et al., (2002) Nature, 416, 636-640)は、脊髄損傷部位へChABCを 直接、持続的に投与することにより春髄損傷の機能的回復を促 進するという報告である。その処理の方法はヒトの臨床応用へ の可能性を示唆するものである。

成熟ウィスターラットの背面側脊髄 (第 4 頸髄)を人工的に 損傷させ、その損傷部位のくも膜下腔内にシリコンチューブを 挿入し投薬口を確保した。そして損傷直後からコンドロイチ ナーゼ $\mathrm{ABC}(\mathrm{Ch} \mathrm{ABC})(10 \mathrm{U} / \mathrm{mL})$ を $6 \mu \mathrm{L}$ 注入した。別のグルー プには損傷後 $\mathrm{ChABC}$ と同量の塩類溶液が注入された。酵素処理 は脊髄損傷後 10 日間 1 日おきに処方された。対照として偽損傷 ラットが用意された。脊髄破壊後 2 週間たったラットを灌流固 定し、その損傷脊髄でCSが分解されているかどうかが 4 硫酸化 不飽和 2 糖を認識する2B6抗体で調べられた。ChABC処理した 損傷部位周辺と白質の拉よそ $4 \mathrm{~mm}$ の広さで CS は分解されてい た。また、再生軸索のマーカーである Growth-associated protein 43 (GAP-43)の発現は ChABC で処理された障害部位周辺にある 背根神経節の一次感覚神経で上昇していた。軸索に発現する GM1 と結合するコレラ毒 B - サブユニットを用いて軸索をラベ ルすると、対照に比べてChABCで処理した組織は障害部位に向 かって軸索が伸長していた。その軸索には成長円錐が観察され た。腰髄で脊髄皮質神経路 (CST)のマーカーであるプロテイン 
axon tips in rats infused with ChABC. Protein kinase C- $\gamma$ immunoreactivity (a marker of the corticospinal tract (CST)) was lost in the CST at lumbar level of lesioned animals, showing complete transection of this tract. ChABC treatment promoted regeneration of CST as assessed by biotinylated dextran amine labeling. In ChABC-treated animals, some axons sent arborizing collaterals from white matter to grey matter. Anatomically, elongation of axon was evident in ChABC-treated rats.

Anatomical regeneration of axon, however, does not necessarily mean functional recovery. Functional recovery can be achieved only after formation of right projection. The authors estimated the functional recovery of sensory and motor axon by electophysiological experiments and behavior of the animals. Spinal cord injury abolished postsynaptic potentials evoked by the cortical stimuli below the lesion. ChABC-treated animals showed the large potential up to $7 \mathrm{~mm}$ below the lesion, while in control animals the potential was only minimal below the lesion. Postsynaptic potential recovered after ChABC treatment was abolished by re-section, indicating that the recovery after $\mathrm{ChABC}$ treatment is due to new connections of regenerated CST axons. When rats crossed a narrow beam or grid, unlesioned sham controls made few foot slips, but lesioned rats without ChABC treatment were severely impaired. ChABC treatment produced a marked recovery of function after one or two weeks. On analysis of footprint spacing, ChABC treatment corrected short and wide strides that were observed in lesioned rats without ChABC treatment.

Several reports have appeared describing regeneration of axon. However, recovery of precise projection that was present in the normal nervous system is critically important for treating neural injury. This paper showed that not only regeneration of axon but also functional recovery were attained by $\mathrm{ChABC}$ infusion into the lesioned sites. ChABC treatment described in this paper may provide a novel medical treatment for spinal cord injury in the near future, although it remains to be investigated whether functional recovery observed in rats is also achieved in human.

Nogo, neurite outgrowth inhibitor ;

CSPGs, chondroitin sulfate proteoglycans;

MAG, myelin associated glycoprotein.

\section{Reported by Yusa, Akiko; and Habuchi, Osami}

Aichi University of Education

1-Hirosawa, Igaya-cho, Kariya, Aichi 448-8542, Japan

FAX: 0566-26-2649
キナーゼ C $-\gamma$ の染色性が失われることから、脊髄損傷を起こ すと順行性の経路が遮断されることが分かる。順行性マーカー であるビオチン化デキストランアミンでラベルしてCSTを観察 すると、対照に比べChABC処置を施したラットでは明らかな伸 長が見られ、また、白質から灰白質への枝分かれ構造も観察さ れた。解剖学的には ChABC処理を行うことで、軸索の明確な伸 長が観察された。

しかし、ただ軸索が再生されても機能回復とは必ずしも一 致しない。正しい投射が再構築されなければ機能は回復しない。 そこで彼らは電気生理学的手法と、運動能力を測定し、感覚と 運動能力の回復を調查した。脊䯣皮質を電気的に刺激しその刺 激に対する反応を調べた結果、脊髄損傷により損傷部位より下 流ではシナプス後電位は消失した。ChABC 処理したラットで は、損傷部より $7 \mathrm{~mm}$ 下方まで応答があり、ChABC未処理のラッ トと比べ、明らかに差があった。また、ChABC処理により回復 したラットの脊髄を再び損傷させると、シナプス後電位はまっ たく見られなくなった。このことから $\mathrm{ChABC}$ 処理による回復 は、他の神経経路からの連結ではなく新しい軸索の結合が再生 したことがわかる。細い板または編み目の上を歩行させたとき、 損傷を受けていないラットはほとんど足を滑らせないが、損傷 を受けたラットはひどく失敗する。ChABC処理ラットでは脊䯣 破壊後 $1 、 2$ 週間後には偽損傷ラットの成績に近づいた。ラッ トの足跡を見ても ChABC未処理のラットに比べChABC処理の ラットの足跡はより正常な状態に近づいていた。

軸索の再生例は数多く報告されている。神経障害の治療に おいて重要なことは正常な状態と同様な正確な投射が再生され ることである。この論文は軸索の再生だけでなく機能回復が起 きたことを報告している。その処理方法がヒトの臨床治療に対 して応用可能であることに注目したい。ラットで回復した機能 がヒトでも同様に回復するかどうかは今後の問題であるが、近 い将来脊髄損傷は回復可能なものとなっているかもしれない。

Nogo: neurite outgrowth inhibitor (神経突起成長阻害因子)

CSPGs: chondroitin sulfate proteoglycans (コンドロイチン硫酸プ ロテオグリカン)

MAG: myelin associated glycoprotein(ミエリン会合糖蛋白質)

愛知教育大学

遊佐 亜希子、羽㴊 脩躬 